Pesq. Vet. Bras. 36(12):1165-1170, dezembro 2016 DOI: $10.1590 / \mathrm{S} 0100-736 \mathrm{X} 2016001200004$

\title{
Frequency, serotyping and antimicrobial resistance pattern of Salmonella from feces and lymph nodes of pigs ${ }^{1}$
}

\author{
João B.P. Guerra Filho², Ricardo S. Yamatogi², Fábio S. Possebon², Sueli A. \\ Fernandes ${ }^{3}$, Monique R. Tiba-Casas ${ }^{3}$, Gustavo H.B. Lara², Márcio G. Ribeiro² \\ and José P.A.N. Pinto ${ }^{2 *}$
}

\begin{abstract}
Guerra Filho J.B.P., Yamatogi R.S., Possebon F.S., Fernandes S.A., Tiba-Casas M.R., Lara G.H.B., Ribeiro M.G. \& Pinto J.P.A.N. 2016. Frequency, serotyping and antimicrobial resistance pattern of Salmonella from feces and lymph nodes of pigs. Pesquisa Veterinária Brasileira 36(12):1165-1170. Departamento de Higiene Veterinária e Saúde Pública, Faculdade de Medicna Veterinária e Zootecnia Universidade Estadual Paulista, Distrito de Rubião Júnior s/n, Botucatu, SP 18618-970, Brazil. E-mail: josepaes@fmvz.unesp.br

Salmonellosis is a foodborne disease caused by bacteria of the genus Salmonella, being pigs and pork-products potentially important for its occurrence. In recent decades, some serovars of Salmonella have shown increase of resistance to conventional antimicrobials used in human and animal therapy, with serious risks for public health. The aim of this study was to evaluate feces $(n=50)$, mediastinal $(n=50)$, mesenteric $(n=50)$ and mandibular $(\mathrm{n}=50)$ lymph nodes obtained from slaughter houses for Salmonella spp. Positive samples were serotyped and subjected to an in vitro antimicrobial susceptibility test, including the extended-spectrum beta-lactamase (ESBL) production. Salmonella species were identified in 10\% (20/200) of total samples. From these, 20\% (10/50) were identified in the submandibular lymph nodes, $18 \%(9 / 50)$ in the mesenteric lymph nodes, $2 \%(1 / 50)$ in feces and $0 \%(0 / 50)$ in the mediastinal lymph nodes. The serotypes found were Salonella Typhimurium (55\%), S. enterica subsp. enterica 4,5,12: i: - (35\%), S. Brandenburg and $S$. Derby with 5\% (5\% each). All strains showed resistance to at least one antimicrobial; $90 \%$ were resistant to four or more antimicrobials, and 15\% were multidrug-resistant. Resistance to ciprofloxacin, tetracycline and nalidixic acid was particularly prevalent amongst the tested serovars. Here, we highlighted the impact of pigs in the epidemiological chain of salmonellosis in domestic animals and humans, as well as the high antimicrobial resistance rates of Salmonella strains, reinforcing the necessity for responsible use of antimicrobials for animals as an emergent One Health issue, and to keep these drugs for human therapy approaches.
\end{abstract}

INDEX TERMS: Serotyping, antimicrobial resistance, Salmonella, feces, lymph nodes, pigs, pork, multidrug-resistant, epidemiology, serovars.

RESUMO.- [Isolamento, sorotipagem e padrões de resistência a antimicrobianos de Salmonella em fezes e linfonodos de suínos.] Nas últimas décadas, o aumento de cepas circulante de Salmonella concomitantemente

\footnotetext{
${ }^{1}$ Received on November 20, 2015.

Accepted for publication on June 16, 2016.

${ }^{2}$ Departamento de Higiene Veterinária e Saúde Púbica, Faculda de Medicina Veterinária e Zootecnia, Universidade Estadual Paulista (Unesp), Distrito de Rubião Júnior s/n, Botucatu, SP 18618-970, Brazil. *Corresponding author: josepaes@fmvz.unesp.br

${ }^{3}$ Instituto Adolfo Lutz, Av. Doutor Arnaldo 351, São Paulo, SP 01246902, Brazil.
}

a resistência microbiana tem despertado a preocupação dos órgãos de Saúde Pública. Deste modo, o objetivo do presente trabalho foi pesquisar a presença de Salmonella a partir de fezes $(n=50)$, linfonodos mediastinos $(n=50)$, mesentéricos $(n=50)$ e submandibular $(n=50)$ oriundos de um abatedouro suíno. As cepas isoladas foram sorotipadas e testadas quanto a resistência antimicrobiana. A presença de Salmonella isolada foram em 10\% (20/200) do total de amostras, sendo $20 \%$ dos linfonodos submandibulares, $18 \%$ dos linfonodos mesentéricos e $2 \%$ das fezes. Os sorotipos encontrados foram $S$. Typhimurium (55\%), S. enterica subsp. enterica 4,5,12: i: - (35\%), $S$. Brandenburg (5\%) e $S$. 
Derby (5\%). Todas a cepas apresentaram resistência a pelo menos um antimicrobiano testado, sendo $90 \%$ resistente pelo menos quatro antimicrobianos. Destes, 15\% foram classificadas como multidrogas resistentes. Os antimicrobianos mais resistentes entre os sorovares isolados foram a ciprofloxacina, tetraciclina e o ácido nalidixico. A presença de cepas de Salmonella resistente a antimicrobianos na espécie suína tem gerado um grande impacto epidemiológico entre homem e animal, reforçando cada vez mais a necessidade do uso adequado de drogas principalmente relacionado com o tema "One Health".

TERMOS DE INDEXAÇÃO: Isolamento, sorotipagem, resistência, antimicrobianos, Salmonella, fezes, linfonodos, suínos, multidrogas resistentes, epidemiologia, sorovares.

\section{INTRODUCTION}

Foodborne diseases always offer great risks, despite the attention given for their control. The increased production in a global scale has contributed to foodborne cases and outbreaks, resulting on serious public health concern (Carrasco et al. 2012). Today, salmonellosis is the most frequent foodborne disease in the world (Bollaerts et al. 2008), reaching 131,468 annual human cases reported in the European Union (Carrasco et al. 2012), and 45,828 in the United State (CDC 2013), even when the occurrence of mild symptoms leads to an underestimated notification (Santos et al. 2002).

Brazil is considered the 4th largest producer of pork in the world, second only to China, European Union and United States, respectively, reaching an annual production over 3 million tons and exports over 600 thousand tons in 2013 (ABIPECS 2013). In this country, from 2000 to 2013, were reported 8,871 foodborne diseases outbreaks, being Salmonella the causative agent in 1,522 of them. Among these total outbreaks, 277 (4.26\%) were associated with pork products.

Salmonella is closely related to the swine production chain, being isolated in several production steps, including primary production, transport of animals, the pre-slaughter and pre-evisceration steps, especially during scalding, opening of the abdomen and withdrawing of colon (Letellier et al. 2009, Duggan et al. 2010, Carrasco et al. 2012, Gomes-Neves et al. 2012). Salmonella infections in pigs occurs through oral infection, and later spreads to the lymphatic system, which acts as barrier at the first moment, but can become reservoirs posteriorly allowing environmental-elimination of the agent and its dissemination through other animals (Straw et al. 2012). Therefore, the isolation of Salmonella from pigs' lymph nodes indicates its carrier status and the analysis of intestinal contents is related to its excretory potential (Davies et al. 1998, Bahnson et al. 2006).

In recent decades, $S$. Enteritidis and $S$. Typhimurium serovars have caused great concern (Bollaerts et al. 2008). In most cases where humans have contracted one of these serovars, the pathogen infection is self-limiting, characterized by gastroenteritis. However, in some cases the manifestations are more severe, especially in immunocompromised patients (EFSA 2010). In these cases, the conventional treatment for salmonellosis is based on fluoroquinolones and quinolones antimicrobials for adults, third-generation cephalosporins for children, and chloramphenicol in patients with endocarditis or endovascular infection (Lesser \& Miller 2005, EFSA 2010). Nevertheless, several studies have pointed out the isolation of multidrug-resistant Salmonella strains, including to the main drugs of choice in the therapeutic practices for veterinary and human protocols (EFSA 2010).

In the European Union is recorded occurrence of multidrug-resistant strains in 16 countries for pigs, and 14 countries for pork samples (EFSA 2010). In Spain, studies report Salmonella resistance to streptomycin (46\% of tested serovars), tetracycline (30\%), sulfonamides (25\%) and ampicillin (23\%), with $36 \%$ of serovars multidrug-resistant (Gomez-Laguna et al. 2011). In a similar study conducted in Vietnam, from poultry and pork meat strains, resistance of Salmonella to at least one antimicrobial was found in $78.4 \%$ of samples, with $23.2 \%$ MDR (Thai et al. 2012). In a study carried out in Brazil, different serotypes of Salmonella isolated from pigs showed resistance to sulfonamides (83.9\%), tetracycline $(37.4 \%)$, cotrimoxazole $(25.2 \%)$, ampicillin (20.2\%), chloramphenicol (16.1\%), streptromycin (14.1\%), and nalidixic acid (10.1\%), and $24.2 \%$ were formally multidrug-resistant (Castagna et al. 2001).

It is well recognized that the Enterobacteriaceae family includes many species that produce enzymes that hydrolyze beta lactam antibiotics. One of the predominant enzymes, Extended Spectrum Beta Lactamase (ESBL), inactivates penicillins, cephalosporins and monobactams (Sousa Junior et al. 2004).

Here, we investigated the frequency of Salmonella spp. in feces, mesenteric, mediastinal and submandibular lymph nodes from pigs, as well as serotype characterization and in vitro resistance profile of strains to several antimicrobials, choosen based on Clinical Laboratory Standards Institute guidelines (CSLI 2013).

\section{MATERIALS AND METHODS}

Animals and sample collection. Two hundred specimens from pigs were sampled. Of these, 50 fecal samples were collected in the evisceration and inspection tables, using sterile plastic bags and 150 lymph nodes without apparent abnormalities (without lymphadenitis) of pigs were removed from carcasses and placed in sterile plastic bags (being 50 mediastinal, 50 mesenteric and 50 submandibular), taken randomly from different animals. The animals were slaughtered in the finishing phase (150-180 days) in slaughterhouses under Brazilian Federal Inspection Service. Sampled pigs came from up 20 piggeries of 10 different cities located in Sao Paulo and Santa Catarina States, Brazil. The animals were from medium scale farms housing between 350-950 animals kept in intensive indoors system, with concrete-floored, and fed exclusively with commercial feed. Immediately after collection, the samples were kept refrigerated $\left(4-8^{\circ} \mathrm{C}\right)$ and stored at $-20^{\circ} \mathrm{C}$ until the diagnostic procedures.

Salmonella identification. For the isolation of Salmonella spp., the samples defrost under refrigeration for 24 hours. Feces samples were fractionated in $1 \mathrm{~g}$ aliquots and packed in sterile plastic bags. Samples of lymph nodes were externally disinfected with alcohol $70 \%$ and then fractionated to obtain a $1 \mathrm{~g}$ aliquot, which was also transferred to sterile plastic bag. For each bag was added $9 \mathrm{~mL}$ of buffered peptone water $1 \%(\mathrm{BPW})\left(\mathrm{Oxoid}^{\circledR}\right.$, 
Hampshire - England), homogenized and incubated for $24 \mathrm{~h}$ at 35 ${ }^{\circ} \mathrm{C}$. Subsequently the enrichment step, were transferred $0.1 \mathrm{~mL}$ of pre-enrichment to $10 \mathrm{~mL}$ of Rappaport-Vassiliadis broth (RV) and $1 \mathrm{~mL}$ to $10 \mathrm{ml}$ of Tetrathionate broth (TT). TT tubes were incubated at $35^{\circ} \mathrm{C}$ for 18 to 24 hours and RV incubated $42^{\circ} \mathrm{C}$ for 18 to 24 hours. Each broth was then streak on plates containing xylose lysine desoxycholate (XLD - Oxoid ${ }^{\circledR}$ ), bismuth sulfite agar (BS - Oxoid ${ }^{\circledR}$ ) and incubated for 24 hours at $35^{\circ} \mathrm{C}$. The colonies compatible with Salmonella spp. were transferred to triple sugar iron agar (TSI - Oxoid ${ }^{\circledR}$ ) and lysine iron agar (LIA - Oxoid ${ }^{\circledR}$ ) for preliminary biochemical tests, incubated for 18 to $24 \mathrm{~h}$ at $35^{\circ} \mathrm{C}$. Salmonella suspected colonies were subjected to follow conventional phenotypic tests: indole, motility, phenylalanine desaminase and urease production, Methyl Red and Voges-Proskauer reactions, citrate, glucose and lactose utilization. The samples with typical biochemical characteristics were confirmed by agglutination test in polyvalent antiserum specific for Salmonella spp (Probac ${ }^{\circledR}$, São Paulo, Brazil).

Microbiological identification of Salmonella spp. was performed according to Andrews et al. (2014). The strains were serotyped using the somatic 0 , phase 1 and phase 2 of the $\mathrm{H}$ flagellar antigens by agglutination tests with antisera prepared in the Laboratory of Enteric Pathogens, Institute Adolfo Lutz, São Paulo as specified in the White-Kauffmann-LeMinor protocol for Salmonella serotyping (Grimont \& Weil 2007).

In vitro antimicrobial susceptibility test. For the antimicrobial resistance investigation, the strains were subjected to the Bauer-Kirby disk diffusion method, according to the guidelines recommended by Clinical and Laboratory Standards Institute (CSLI, 2013). The antimicrobial agents were: nalidixic acid - $30 \mathrm{~g}$

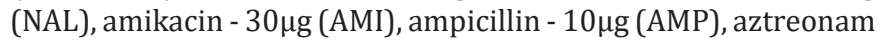

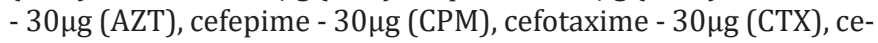

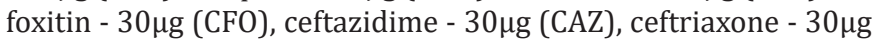
(CRO), ciprofloxacin - $5 \mu \mathrm{g}$ (CIP), chloramphenicol - 30 $\mu$ g (CLO),

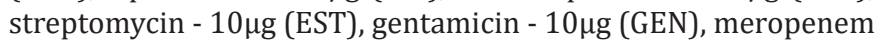
(MER), sulfonamides - 300 $\mathrm{g}$ (SUL), trimethoprim-sulfametoxa-

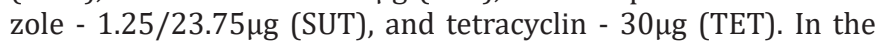
current study, the intermediate resistant strains were considered resistant (CDC 2014).

ESBL production. Ciprofloxacin resistant strains were tested for ESBL enzyme presence by the method of double disk diffusion to check synergism between clavulanic acid and aztreonam, ceftazidime, ceftriaxone and cefotaxime. Resistant strains were identified by the formation of a secondary inhibition halo by a synergism of the tested antimicrobials with the initial intersection of the inhibition zones of each antimicrobial (CSLI 2013).

Statistical analysis. Logistic regression analysis was used in the binomial dependent variable, using the PROC LOGISTIC of the Statistical Analysis Software (SAS ${ }^{\circledR}$ 9.4, Inst. Inc., Cary, NC, USA). The results are shown as a percentage. For all analyzes, were adopted the significance level of $5 \%(\mathrm{P}<0.05)$.

\section{RESULTS}

Salmonella strains were identified in $10 \%(n=20 / 200)$ of samples. The highest rates were found in the submandibular lymph nodes $(\mathrm{n}=10 / 50,20 \%)$, followed by mesenteric lymph nodes $(n=9 / 50,18 \%)$. In contrast, the lowest prevalence were found in fecal samples $(n=1 / 50,2 \%)$. No strain of the pathogen was isolated in mediastinal lymph nodes. Mesenteric and submandibular lymph nodes showed statistical similarity ( $p>0.05)$ but differed when compared to samples of feces and mediastinal lymph nodes $(\mathrm{p}<0.05)$ (Table 1).
The serotyping of the 20 isolated strains identified the following serotypes: $S$. Typhimurium $(\mathrm{n}=11 / 20,55 \%), S$. enterica subsp. enterica 4,5,12: i: - $(\mathrm{n}=7 / 20,35 \%)$, and $S$. Brandenburg and $S$. Derby (n=1/20, 5\% each).

The highest antimicrobial resistance rates of isolates were found for ciprofloxacin (CIP) and tetracycline (TET) $(\mathrm{n}=18 / 20,90 \%$ each), followed by nalidixic acid (NAL) $(\mathrm{n}=16 / 20,80 \%)$.

$S$. Typhimurium strains showed resistance to several antimicrobials, especially in relation to tetracycline $(n=11 / 11)$, followed by ciprofloxacin $(n=10 / 11)$, nalidixic acid, sulfonamides and chloramphenicol $(n=8 / 11)$, streptomycin $(n=7 / 11)$, trimethoprim-sulfamethoxazole $(n=6 / 11)$, ampicillin $(n=4 / 11)$, and gentamicin and cefotaxime (n=1/11) (Fig.1).

A total of $S$. enterica subsp. enterica 4,5,12: i: - strains $(\mathrm{n}=7 / 7)$ showed resistance to nalidixic acid, sulfamethoxazole trimethoprim-sulfonamides, tetracycline and streptomycin. For the other antimicrobials the resistant values of isolates were $n=6 / 7$ for ciprofloxacin, $n=5 / 7$ for chloramphenicol and $n=1 / 7$ to ampicillin, gentamicin and cefotaxime (Table 2).

Table 1. Number, frequency and serovars of Salmonella positive lymph nodes and feces from slaughtered pigs

\begin{tabular}{|c|c|c|c|}
\hline Sample & $\mathrm{N}$ & Positives (\%) & Serovars \\
\hline $\begin{array}{l}\text { Submandibular } \\
\text { lymph nodes }\end{array}$ & 50 & $10(20 \%)^{a}$ & $\begin{array}{c}\text {-S. enterica subsp. enterica } \\
\text { 4,5,12:i:- } \\
\text {-S. Typhimurium }\end{array}$ \\
\hline $\begin{array}{l}\text { Mesenteric lymph } \\
\text { nodes }\end{array}$ & 50 & $9(18 \%)^{a}$ & $\begin{array}{c}\text {-S. Typhimurium } \\
-S . \text { Derby } \\
-S . \text { Brandenburg }\end{array}$ \\
\hline Feces & 50 & $1(2 \%)^{b}$ & $\begin{array}{c}\text {-S. enterica subsp. enterica } \\
4,5,12: \mathrm{i}:-\end{array}$ \\
\hline $\begin{array}{l}\text { Mediastinal lymph } \\
\text { nodes }\end{array}$ & 50 & $0(0 \%)^{\mathrm{b}}$ & - \\
\hline TOTAL & 200 & $20(10 \%)$ & 4 serovars \\
\hline
\end{tabular}

$\overline{a, b}$ Different letters indicates statistical difference $(p<0.05)$ in the percentage of positives for each sample type.

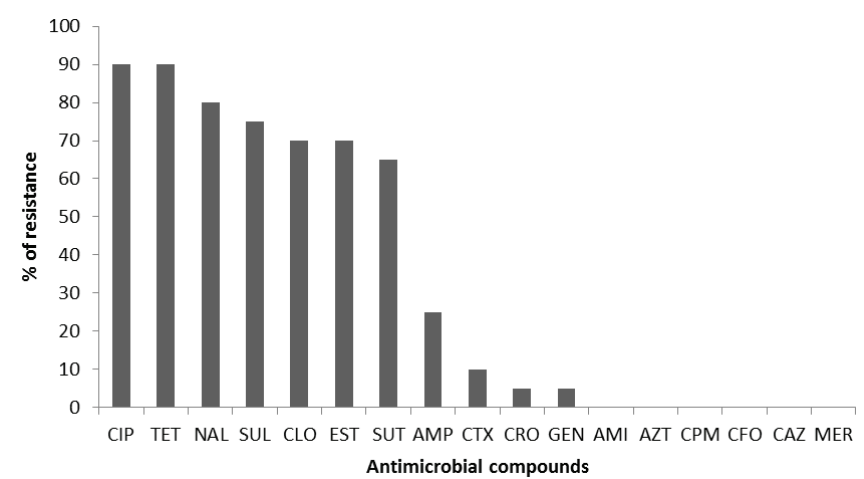

Fig.1. Percentage of resistant Salmonella strains isolated from swine feces and lymph nodes for the tested antimicrobial compounds. Ciprofloxacin (CIP), Tetracycline (TET), Nalidixic Acid (NAL), Sulfonamides (SUL), Chloramphenicol (CLO), Streptomycin (EST), Sulfamethoxazole-trimethoprim (SUT), Ampicillin (AMP), Cefotaxime (CTX), Ceftriaxone (CRO), Gentamicin (GEN) Amikacin (AMI), Aztreonam (AZT), Cefepime (CPM), Cefoxitin(CFO), Ceftazidime (CAZ) Meropenem (MER). 
Table 2. Antimicrobial resistance profile of different serotypes of Salmonella isolated from slaughtered pigs

\begin{tabular}{lc}
\hline \multicolumn{1}{c}{ Serovar } & Antimicrobial \\
\hline S. Typhimurium & CIP \\
S. Brandenburg & CIP, CRO \\
S.Typhimurium & NAL, CIP, CLO, TET \\
S. Typhimurium & CIP, SUT, SUL, TET \\
S. Typhimurium & NAL, CIP, CLO, EST, TET \\
S. Typhimurium & NAL, CTX, CIP, CLO, TET \\
S. Typhimurium & NAL, AMP, CIP, SUL, TET \\
S. enterica subsp. enterica 4,5,12:i:- & NAL, CIP, SUT, SUL, EST, TET \\
S. Typhimurium & AMP, CLO, SUT, SUL, EST, TET \\
S. Typhimurium & AMP,CIP, CLO, SUL, SUT, EST, TET \\
S. Derby & AMP,CIP, CLO, EST,SUL, SUT, TET \\
S. Typhimurium & NAL, CIP, CLO, SUT, SUL, EST, TET \\
S. enterica subsp. enterica 4,5,12:i:- & NAL, CIP, CLO, SUT, SUL, EST, TET \\
S. enterica subsp. enterica 4,5,12:i:- & NAL, CIP, CLO, SUT, SUL, EST, TET \\
S. Typhimurium & NAL, CIP, CLO, SUT, SUL, EST, TET \\
S. enterica subsp. enterica 4,5,12:i:- & NAL, CIP, CLO, SUT, SUL, EST, TET \\
S. enterica subsp. enterica 4,5,12:i:- & NAL, CIP, CLO, SUT, SUL, EST, TET \\
S. Typhimurium & NAL, CIP, CLO, SUT, SUL, EST, TET \\
S. enterica subsp. enterica 4,5,12:i:- & NAL, AMP, SUT, GEN, SUL, EST, TET \\
S. enterica subsp. enterica 4,5,12:i:- & NAL, CTX, CIP, CLO, SUT, SUL, EST, TET
\end{tabular}

Ciprofloxacin (CIP), Tetracycline (TET), Nalidixic acid (NAL), sulfonamides (SUL), chloramphenicol (CLO), streptomycin (EST), Trimethoprim-sulfamethoxazole (SUT), ampicillin (AMP), cefotaxime (CTX), ceftriaxone (CRO), Gentamicin (GEN).

The only one $S$. Brandenburg strain shows resistance exclusively to ciprofloxacin and ceftriaxone. The other single isolate of $S$. Derby was resistant against ampicillin, trimethoprim-sulfamethoxazole, sulfonamides, streptomycin, tetracycline, chloramphenicol and ciprofloxacin (Table 2).

Among the serovars identified, all were resistant to at least one of the antimicrobials tested, with $90 \%$ of them $(\mathrm{n}=18)$ resistant to at least four antimicrobial simultaneously. Considering the standards determined by CLSI for MDR samples, simultaneously resistant to ampicillin, chloramphenicol, streptomycin, trimethoprim-sulfamethoxazole and tetracycline, $15 \%(\mathrm{n}=3)$ of the samples showed this pattern (Table 2). There was no strain positive for the ESBL enzyme production.

\section{DISCUSSION}

The present study revealed 10\% frequency of Salmonella isolated from fecal and lymph nodes of pigs. This result is relatively lower to similar studies described worldwide. In Portugal, Vietnam and European Union were reported respectively $17.6 \%, 34.8 \%$ and $33 \%$ of positive identification of Salmonella in pigs (EFSA 2010, Ellerbroek et al. 2010, Gomes-Neves et al. 2012). Particularly in Brazil, different studies carried out in different regions revealed $16.6 \%$ and $67 \%$ of Salmonella from slaughtered pigs (Bessa et al. 2004, Sanchez et al. 2007, Silva et al. 2009, Kich et al. 2011).

Salmonella was most prevalent in the submandibular and mesenteric lymph nodes, then feces, and then mediastinal lymph nodes. It is known that the amount of feces sampled is related to the chances of the pathogen isolation (Davies et al. 1998), so the lower isolation rate in feces can be related to the sample aliquot used $(1 \mathrm{~g})$. Other factor which can be associated to the lower frequency of Salmo- nella in the fecal samples is the intermittent excretion of the pathogen. On the other hand, Salmonella is present intracellularly in the lymph nodes, which acts as reservoirs of the pathogen (Bahnson et al. 2006), being less exposed to other factors that would difficult the pathogen detection by the isolation technique, being the presence of Salmonella in the lymph nodes an indicator of the carrier status of the animal.

The differences observed in the isolation of Salmonella from specific lymph nodes relates to the anatomical position of them. The most prevalent occurrence of the pathogen was observed in the mesenteric and submandibular lymph nodes. The high prevalence of Salmonella in mesenteric and submandibular lymph nodes is associated with the proximity of them, respectively, to the gastrointestinal fecal contents, taking these nodes as an initial barrier to the pathogen. In many cases, the submandibular infection does not develop enteric signs, turning the animals into reservoirs. In fact, the oral-fecal cycle of Salmonella infections in pigs was investigated in other studies, showing that $70 \%$ of the isolates were identified in the tonsils and submandibular lymph nodes (Bahnson et al. 2006, Straw et al. 2012).

The high occurrence of $S$. Typhimurium identified in pigs sampled, agreed with increased prevalence of this serotype in the global scenery (Carrasco et al. 2012). In 2011, $S$. Typhimurium was also the predominant serovar reported in the United States, followed by $S$. Enteritidis (CDC 2013). The high prevalence of this serovar has been reported in European Union (EFSA 2010) and Brazil (Kich et al. 2011) as well.

Another relevant finding in the current study is 35\% $(\mathrm{n}=7 / 20)$ of positive isolation of $S$. enterica subsp. enterica $4,5,12$ : i-, a serotype considered similar to $S$. Typhimurium, characterized by minor differences in the flagellar phase. Currently, S. enterica subsp. enterica 4,5,12: i- is referred as one of the main serotypes isolated from pigs worldwide, particularly in Europe (EFSA 2010) and the United States, since it notifications increased $351 \%$ between 2001 and 2011 (CDC 2013). This monophasic Typhimurium-like strains are considered an emerging pathogen, being associated to several outbreaks with high antibiotic resistance rates, however Brazilian data about this serovar isolation are still scarse.

The others serotypes also identified in the present study, as $S$. Brandenburg and $S$. Derby, only one sample each, have similar results to those observed in other countries (Kich et al. 2011, Carrasco et al. 2012, Thai et al. 2012).

In the current study, up $80 \%$ of strains were found to be resistant to ciprofloxacin, tetracycline and nalidixic acid. Similar studies in Brazil have also found a prevalence of resistance by Salmonella isolated from pigs to tetracycline (96.5\%) and nalidixic acid (95.5\%) (Castagna et al. 2001), as well as multidrug resistant strains particularly to sulfonamides $(97.8 \%)$ and streptomycin $(82.6 \%)$ (Weiss et al. 2002). The high resistance rates of our isolates for ciprofloxacin are similar to those found in pigs from Spain (97.1\%) (EFSA 2010). In contrast, studies in other countries revealed minor occurrence of resistant Salmonella strains against tetracycline, sulfonamides and nalidixic 
acid (Gomez-Laguna et al. 2011, Thai et al. 2012). Interestingly, ciprofloxacin, tetracycline and nalidixic acid that showed low effectiveness in our Salmonella strains, are considered antimicrobials of choice to humans and animal therapy of salmonellosis (Lesser \& Miller 2005, Radostits et al. 2007).

The high prevalence antibiotic-resistant strains of Salmonella encountered in our study is similar to the reported in other studies, such as investigations in pigs from Vietnam, Estonia, Ireland and Brazil. These studies reported multidrug resistance frequencies of $23.2 \%, 13.6 \%, 59.4 \%$ and $24.2 \%$, respectively (EFSA 2010, Thai et al. 2012)

Multidrug resistant bacteria, including Salmonella species from animal and human origin is an emergent public health concern (Giguère et al. 2010). The high antimicrobial resistance rates in pig production can be attributed, among other reasons, to the improper use of antimicrobials for treatment of diseases or growth promotion in pork production (Gebreyes et al. 2004, Kich et al. 2011, Gomes-Neves et al. 2012). However, some resistance mechanisms to some antimicrobials are easily transferred between species, and their prevalence may be in part be due to environmental contamination. Another important resistance acquisition route are the genes that promotes simultaneous resistance to different compounds. In the light of this, ubiquitous and opportunistic pathogenic bacteria as Salmonella with resistance to conventional antimicrobials can survive in environment of farms, and are able to transmit drug resistance to other bacteria that infect wildlife and domestic animals, including pigs (Thakur et al. 2007). Indeed, despite the prohibition of the use of chloramphenicol in livestock 25 years ago in United States (Thakur et al. 2007) and 18 years ago in Brazil (Brasil 2003), a diverse range of bacteria remain resistant to these drugs even today.

In our study were not detected Salmonella strains ESBL-enzyme positive. However, in Europe ESBL production was referred in $0.6 \%$ of the strains isolated from pigs, when tested for cefotaxime and $0.5 \%$ for ceftazidime (EFSA 2014). Despite absence of Salmonella strains positive for ESBL-production in pigs sampled, the emergence of this pathogenic mechanism of antimicrobial resistance of Salmonella, requires continuous epidemiological vigilance studies.

In this study, we found that Salmonella spp. isolated from pigs exhibit high levels of resistance to antimicrobials. These antibiotic-resistant strains may potentially cause foodborne outbreaks of antibiotic-resistant salmonella in humans. $S$. Typhimurium was the most common serovar, even with the adoption of control measures implemented over several decades in pig farms. In addition, there is an increasing occurrence of $S$. enterica subsp. enterica 4,5,12: i: -, considered an emergent human pathogen and with few Brazilian data about this serovar available. The high resistance rates found in our study reveals that despite regional differences for resistance to some antimicrobials, the inappropriate use of antimicrobials increases the selection rate of multidrug resistant bacteria, including Salmonella. Thus, the selection of first-choice antimicrobial treatment should be based on local in vitro resistance patterns. Indeed, the responsible use of antimicrobials for animals is an emergent One Health concern, to conserve these drugs for human therapy approaches.

Acknowledgements.- To Adolfo Lutz Institute for conducting the serotyping of strains and Cefar Diagnostic for providing the antibiogram discs.

Conflict of Interest.- No conflict of interest.

\section{REFERENCES}

ABIPECS 2013. Produção mundial de carne suína. Associação Brasileira da Indústria Produtora e Exportadora de Carne Suína.

Andrews W.H., Jacobson A. \& Hammack 2014. BAM Chapter 5: Salmonella, p.5.01-05.020. In: Food and Drug Administration (Ed.), Bacteriological Analytical Manual. 8th ed. AOAC International, Gaithersburg.

Bahnson P.B., Damman D.J., Isaacason R.E., Miller G.Y. \& Weigel R.M. 2006. Prevalence and serovars of Salmonella enterica isolated from ileocolic lymph nodes of market pigs reared in selected Midwest US swine herds. J. Swine Health Prod. 4:182-188.

Bessa M.C., Costa M.D. \& Cardoso M. 2004. Prevalência de Salmonella sp. em suínos abatidos em frigoríficos do Rio Grande do Sul. Pesq. Vet. Bras. 24:80-84.

Bollaerts K., Aerts M., Faes C., Grijspeerdt K., Dewulf J. \& Mintiens K. 2008. Human salmonellosis: estimation of dose-illness from outbreak data. Risk Analysis 28:427-440.

Brasil 2003. Instrução Normativa no 9, de 27 de junho de 2003. Ministério da Agricultura Pecuária e Abastecimento (MAPA).

Carrasco E., Morales-Rueda A. \& Garcia-Gimeno R.M. 2012. Cross-contamination and recontamination by Salmonella in foods: a review. Food Res. Int. 45:545-556.

Castagna S.M.F., Bessa M.C., Carvalho D.A., Cardoso M. \& Costa M. 2001. Resistência a antimicrobianos de amostras de Salmonella sp. isoladas de suínos abatidos no estado do Rio Grande do Sul. Arq. Fac. Vet. UFRGS 29:44-49.

CDC 2013. Centers for Disease Control, Prevention National Salmonella Surveillance Annual Report - Appendices, 2011. US Department of Health and Human Services, CDC, Atlanta, GA.

CDC 2014. Centers for Desease Control, Human Isolates Final Report, 2012, National Antimicrobial Resistance Monitoring System for Enteric Bacteria (NARMS), p.12-26.

CSLI 2013. Performance standards for antimicrobial susceptibility testing M100-S23. Clinical Laboratory Standards Institute, Wayne, PA.

Davies P.R., Bovee G.E.M., Funk J.A., Morrow W.E.M., Jones F.T. \& Deen J. 1998. Isolation of Salmonella serotypes from feces of pigs raised in a multiple-site production system. J. Am. Vet. Med. Assoc. 212:1925-1929.

Duggan S.J., Mannion C., Prendergast D.M., Leonard N., Fanning S., Gonzales-Barron U., Egan J., Butler F. \& Duffy G. 2010. Tracking the Salmonella satus of pigs and pork from Lairage through the slaughter process in the Republic of Ireland. J. Food Prot. 73:2148-2160.

EFSA 2010. The community summary report on trends and sources of zoonoses, zoonotic gents and food-borne outbreaks in the European Union in 2008. European Food Safety Authority, EFSA J. 8(1):23-110.

EFSA 2014. The European Union Summary Report on antimicrobial resistance in zoonotic and indicator bacteria from humans, animals and food in 2012. European Food Safety Authority, EFSA J. 12:23-51.

Ellerbroek L., Narapati D., Phu Tai N., Poosaran N., Pinthong R., Sirimalaisuwan A., Tshering P., Fries R., Zessin K.H., Baumann M. \& Schroeter A. 2010. Antibiotic resistance in Salmonella isolates from imported chicken carcasses in Bhutan and from pig carcasses in Vietnam. J. Food Prot. 73:376-379.

Gebreyes W.A., Thakur S., Davies P.R., Funk J.A. \& Altier C. 2004. Trends in antimicrobial resistance, phage types and integrons among Salmonella serotypes from pigs, 1997-2000. J. Antimicrob. Chemother. 53:9971003.

Giguère S., Prescott J.F., Baggot J.D., Walker R.D. \& Dowling P.M. 2010. Terapia antimicrobiana em medicina veterinária. Roca, São Paulo. 683p. 
Gomes-Neves E., Antunes P., Tavares A., Themudo P., Cardoso M.F., Gartner F., Costa J.M. \& Peixe L. 2012. Salmonella cross-contamination in swine abattoirs in Portugal: carcasses, meat and meat handlers. Int. J. Food Microbiol. 157:82-87.

Gomez-Laguna J., Hernandez M., Creus E., Echeita A., Otal J., Herrera-Leon S. \& Astorga R.J. 2011. Prevalence and antimicrobial susceptibility of Salmonella infections in free-range pigs. Vet. J. 190:176-178.

Grimont P.A.D. \& Weil F.X. 2007. Antigenic Formulae of the Salmonella Serovars. Institut Pasteur, Centre Collaborater OMS de Référence et de Recherche pour les Salmonella, Paris, France. 166p.

Kich J.D., Coldebella A., Mores N., Nogueira M.G., Cardoso M., Fratamico P.M., Call J.E., Fedorka-Cray P. \& Luchansky J.B. 2011. Prevalence, distribution, and molecular characterization of Salmonella recovered from swine finishing herds and a slaughter facility in Santa Catarina, Brazil. Int. J. Food Microbiol. 151:307-313.

Lesser F.C. \& Miller I.S. 2005. Diseases caused by Gram-negative bacteria, p.901. In: Harrison T.K.D.L., Fauci A.S., Longo D.L., Braunwald E., Hauser S.L. \& Jameson J.L. (Eds), Principles of Internal Medicine. McGraw-Hill Education, New York.

Letellier A., Beauchamp G., Guevremont E., D’Allaire S., Hurnik D. \& Quessy S. 2009. Risk factors at slaughter associated with presence of Salmonella on hog carcasses in Canada. J. Food Prot. 72:2326-2331.

Radostits O.M.G., Gay C.C., Hinchcliff K.W. \& Constable P.D. 2007. Veterinary Medicine: A textbook of the diseases of cattle, horses, sheep, pigs, and goats. Saunders Elsevier, Philadelphia. 2156p.

Sanchez J., Dohoo I.R., Christensen J. \& Rajic A. 2007. Factors influencing the prevalence of Salmonella spp. in swine farms: a meta-analysis approach. Prev. Vet. Med. 81:148-177.

Santos l.R., Nascimento V.P. \& Flores M.L. 2002. Salmonella enteritidis isoladas de amostras clínicas de humanos e de alimentos envolvidos em episódios de toxi-infecções alimentares, ocorridas entre 1995 e 1996, no Estado do Rio Grande do Sul. Hig. Aliment. 16:93-99.

Silva M.C., Faria G.S., Paula D.A.J., Martins R.P., Caramori Junior J.G., Kich J.D., Colodeli E.M., Nakazato l. \& Dutra V. 2009. Prevalência de Salmonella sp. em suínos abatidos no Estado de Mato Grosso. Ciência Rural 39:266-268.

Sousa Junior M.A., Ferreira E.S. \& Conceição G.C. 2004. Betalactamases de espectro ampliado (ESBL): um importante mecanismo de resistência bacteriana e sua detecção no laboratório clínico. Newslab. 63:153174.

Straw B.E., Zimmernman J.J., Karriker l.A., Ramirez A., Schwartz K.J. \& Stevenson G.W. 2012. Diseases of Swine. 10th ed. Wiley-Blackwell, London.

Thai T.H., Hirai T., Lan N.T. \& Yamaguchi R. 2012. Antibiotic resistance profiles of Salmonella serovars isolated from retail pork and chicken meat in North Vietnam. Int. J. Food Microbiol. 156:147-151.

Thakur S., Tadesse D.A., Morrow M. \& Gebreyes W.A. 2007. Occurrence of multidrug resistant Salmonella in antimicrobial-free (ABF) swine production systems. Vet. Microbiol. 125:362-367.

Weiss L.H., Nonig R.B., Cardoso M. \& Costa M.D. 2002. Ocorrência de Salmonella spp. em suínos de terminação no Rio Grande do Sul. Pesq. Vet. Bras. 22:104-108. 